\section{Journal under attack over controversial paper on GM food}

\section{London}

The medical journal The Lancet has been criticized by Britain's Royal Society for publishing a paper on genetically modified (GM) potatoes by controversial author Arpad Pusztai.

The study has been a source of continuing furore in Britain following a statement by Pusztai to the press last year - before any findings had been published that GM foods may stunt the growth of rats. This statement triggered widespread concern over the issue of GM foods. The row continued when the Royal Society reviewed Pusztai's data and concluded that the study was based on flawed design, execution and analysis (Nature 398, 98 \& 399, 188; 1999).

The Lancet's editor, Richard Horton, says the journal raised the threshold for publication of this paper by sending it to six reviewers instead of three, the number normally used. This was because "Pusztai had recklessly made claims about his data a year ago and because of the issue's sensitivity". The paper is accompanied by a commentary by researchers at Wageningen Agricultural University in The Netherlands who are critical of the study's design and conclusions.

But Horton defends the journal's decision to publish the paper, saying that it was made on scientific grounds. "A majority supported publication, but for different reasons. If we hadn't published, it wouldn't be surprising if someone accused us of censorship."

Horton says that one of the benefits of publication is that Pusztai "has had to retract his original claim because his data, which we've published, absolutely don't show that genetically modified foods stunt the growth of rats".

Aaron Klug, president of the Royal Society, said the society would not have published the paper because "it confirms the society's judgement that the experiments were flawed". He said publication had given the study undeserved authenticity.

Peter Collins, the society's senior policy adviser, accuses The Lancet of taking "a very strong position on this. It is clear from an editorial previously published by The Lancet that the editor or the magazine were strongly supportive of Pusztai before they had seen his science. I don't think The Lancet can present its decision to publish Puzstai's paper now as a routine scientific decision.” Natasha Loder

\title{
Japanese guidelines specify the terms of gene patents
}

Tokyo

The Japanese Patent Office (JPO) has released guidelines on human gene patents. These outline its view of the patentability of expressed sequenced tags (ESTs), single nucleotide polymorphisms (SNPs) and fulllength complementary DNA (cDNA) clones.

Although the office reached a general agreement with the US Patent and Trademark Office and the European Patent Office over EST patents in July — namely that such partial DNA sequences cannot be patented without demonstrated utility - its position on other genetic patents had remained unclear.

The new guidelines, unveiled on 5 October, are a response to a call for guidance from Japanese researchers and industry, particularly in the wake of the government's decision to increase support for biotechnology (see Nature 400, 389; 1999).

This initiative includes a planned database of SNPs in the Japanese population, which is hoped to lead to novel drugs and diagnostic techniques, and a project aimed at creating a central repository of cDNA clones for medical and research applications.

The introduction of a technology-transfer bill, based on the US Bayh-Dole legislation, which grants private patents on government-funded research, is also hoped to encourage patent applications from indus- try-university collaborations. JPO officials predict that such projects will lead to a large increase in the number of patent applications on human genes, including SNPs and cDNA clones. In fact, the Helix Research Institute, a genomics company, has already filed patent applications on more than 6,000 full-length human cDNA clones (see Nature 401, 3 \& 520; 1999).

Helix, a joint venture between the Ministry of International Trade and Industry and ten private companies, plans to create a portfolio of intellectual property that can be shared by a planned consortium of 20 biotech companies and research institutes.

But many argue that Helix's patent applications, which largely consist of cDNA clones with unknown functions, are not valid, as they do not demonstrate the invention's utility.

JPO's guidelines on patenting human genes state that the gene must be sequenced and demonstrate utility, such as in diagnosis or treatment. They also specify conditions for patenting a sequence linked to a disease (that is, mutations such as SNPs), which can be used as a probe.

"We may not be successful with obtaining the patents, but the importance lies in the precedent that we have set for patent applications on full-length cDNA clones," says a spokesman for Helix.

Asako Saegusa

\section{Research chair bonanza in Canada}

Montreal

Canadian prime minister Jean Chrétien has announced that the federal government is to fund 2,000 new research chairs at universities, 1,200 of them over the next three years.

"This is incredibly exciting," commented Robert Prichard, president of the University of Toronto. Henry Friesen, president of the Medical Research Council, calls the announcement "stunning".

Chrétien, who has dismissed reports of large-scale emigration of scientists for better opportunities elsewhere, said in his announcement that the plan is "for brain gain, not brain drain".

The plan was proposed by the heads of the research fund-granting councils, the Canada Foundation for Innovation and some university presidents, in particular the rector of the Universite de Montreal, Robert Lacroix, and the president of the University of British Columbia, Martha Piper.

The purpose, said Chrétien, is to "brand"

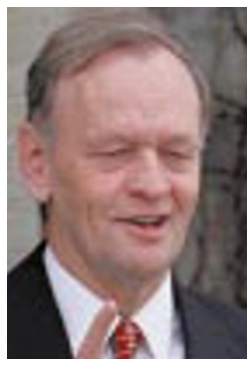

Chrétien: 'brain gain, not brain drain'.
Canada around the world "as the place to be for knowledge creation as we enter the twenty-first century", to enable Canadian universities to create research opportunities for the "best and the brightest Canadians", and to attract "some of the world's best minds" from other countries.

The prime minister failed to mention the cost of the scheme. But Friesen says the total cost of the 2,000 chairs over the first five years will be about Can $\$ 300$ million (US\$200 million).

Support for individual chairs, which could be renewed and revised after five years, will be Can $\$ 100,000$ for younger scientists and Can $\$ 200,000$ for more established researchers; most of this would be in salaries. 
About 35 per cent of the total will go to the biomedical sciences.

"The scale of this is really quite remarkable," says Friesen. Taken together with previously promised increases, the biomedical research budget will be close to Can $\$ 600$ million in five years, Friesen says. "Not so long ago it was a Can $\$ 230$ million commitment."

The proportion of younger to senior research chairs has not been decided. A committee, including the three research granting council presidents and David Strangway, president and chief executive officer of the Canada Foundation for Innovation, will work out the plan's details.

Louis Siminovitch, university professor emeritus at the University of Toronto, sees the initiative as "a great thing", but says "it is not clear what the rules are going to be. Salaries are very important for recruiting people," he adds. "But that's only a very small part of the brain drain. What determines whether a person goes to the United States is research resources."

Siminovitch says the plan "is a very big : step, but it may not be competitive with conditions in the United States. The most important message is that the federal government has awakened to the fact that they've got to do something for research and development."

Another investment of Can $\$ 11$ million : has also been announced by Strangway. He : says it will provide 124 researchers with the : infrastructure necessary to conduct 64 : research projects in 26 Canadian universities and colleges. Because the Canada Foundation for Innovation funds up to 40 per cent of : a project, this investment may trigger a further Can\$16.5 million from other funding partners.

\section{US university fears allayed over access to research data}

\section{Washington}

Final regulations covering access to university researchers' data under the Freedom of Information Act were published in Washington last week. They seem to have gone some way towards satisfying both sides in a bitter dispute over how far such access rights should reach.

The regulations, published by the White House Office of Management and Budget (OMB), will allow raw data to be accessed under the act if these data have been used as the basis for a range of government actions.

But data behind unpublished research results, intellectual property and clinical records of individuals will be exempt. This aspect of the regulations addresses some of the research community's greatest fears.

"We feel that OMB has done a pretty good job - perhaps a better job than seemed possible," says Bill Colglazier, executive officer of the National Academy of Sciences, which has opposed the move to use the act to gain access to researchers' data.

George Leventhal at the Association of American Universities, which represents leading research universities, says: "We think OMB has done well, and we're especially pleased that commercial and personal data will be exempted."

The regulations have also been accepted by Senator Richard Shelby (Republican, Alabama), who championed the legislation ordering OMB to draw them up a year ago. Shelby had objected to the last draft of the

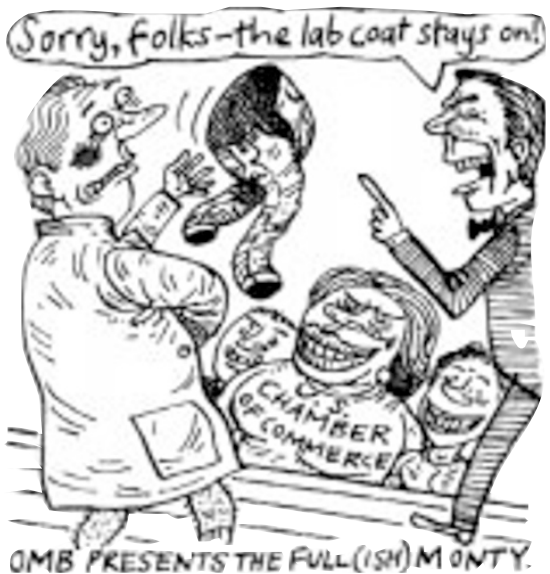

rules, published in August, saying that they allowed too many exemptions.

OMB acceded to Shelby's demand that the act should allow access to data behind all types of government action, not just federal regulations. It also removed a suggestion that the rules should apply only to research whose economic impact was expected to exceed $\$ 100$ million.

The final regulation "is a good first step to giving the American people access to the research and science used in federal policies that affect the lives of Americans each day", Shelby said in a statement.

US business has lobbied hard for access to research results under the act, seeing this as a means of assessing university studies used by the government as the basis for environmental and other regulations.

Colin Macilwain

\section{French students continue to turn away from science}

\section{Paris}

The number of students studying science in French universities and high schools has fallen for the fourth year in a row, according to figures released last week by the ministry for national education, research and technology.

Between 1995 and 1999, the number of first- and second-year university students or students entering for a diplôme d'études universitaires générales (DEUG) - in the sciences fell from 150,000 to 126,400 . The number of high-school students graduating with a science baccalaureate also dropped, from 143,200 to 125,000 .

Officials say the reduced interest at universities stems from the rise in popularity of classes préparatoires, which feed into the prestigious grandes écoles, as well as shorter degree programmes at technical colleges.

\begin{tabular}{|c|c|}
\hline \multicolumn{2}{|c|}{$\begin{array}{l}\text { Students in science DEUG programmes at } \\
\text { French universities }\end{array}$} \\
\hline Year & Number of students \\
\hline 1994-95 & 145,699 \\
\hline $1995-96$ & 149,688 \\
\hline 1996-97 & 143,759 \\
\hline 1997-98 & 134,447 \\
\hline 1998-99 & 126,403 \\
\hline
\end{tabular}

A survey distributed to 3,000 high-school students in April also shows that universities have a poor reputation among students, who think the quality of education is much lower than in the grandes écoles.

France is not alone when it comes to students straying from science. Statistics are similar elsewhere in Europe and the United States. The presidents of Europe's physics societies met last month in the United Kingdom to discuss the lack of students (see
Nature 401, 102; 1999). In Germany, for example, the number of first-year physics students has halved to 5,000 since 1991 .

Physics appears to be the worst hit of the sciences. "Students are turning away from the 'hard' sciences, especially physics, and are more attracted by biology and astronomy," says Claude Feuerstein, president of the University Joseph Fourier at Grenoble. "It's not that it is difficult to find a job after studying physics, in fact it may even be easier than after completing a biology degree."

Feuerstein hopes that reforms, including an emphasis on experimentation over theory and even a marketing campaign, will boost the image of physics and the other hard sciences. "Students need an attractive context and to know why they are learning this."

Heather McCabe 